\title{
New E-Commerce Model and Development Strategy of Fresh Food E-Commerce Platform Based on ReTech
}

\author{
Xi Sun ${ }^{1}$ \\ ${ }^{1}$ Beijing University of Agriculture, Beijing, 102206, China
}

\begin{abstract}
With the arrival of the new retail format, almost every e-commerce platform has arranged fresh food retail one after another. Retech integrates retail and technology organically to enhance the core competitiveness of retail industry in the aspects of automation and intelligence. This paper introduces the four business models of fresh e-commerce and the transformation of circulation model of agricultural products, compares the circulation model of traditional retail and fresh e-commerce, analyses the characteristics of consumption demand of fresh e-commerce, and gives the development strategy of fresh e-commerce platform based on Retech.
\end{abstract}

\section{Introduction}

Retech, the merger abbreviation of retail and technology, refers to the use of digitalization, automation and intelligence to enhance the core competitiveness of the retail industry among venues, goods and buyers and sellers. Fresh e-commerce refers to the direct sale of fresh products, including vegetables, fruits, meat, poultry, eggs and milk, aquatic products and other products of ecommerce model, namely internet marketing. With the wide application of electronic payment, the flexibility and convenience of distribution forms and the safety of contactless shopping, it has brought great changes in the way of shopping to the majority of consumers, and fresh food e-commerce has gradually integrated into people's life.

\section{Four business models and four development stages of fresh food e- commerce}

\subsection{Four business models of fresh food e- commerce}

Pre-warehouse model. There is no physical store in the pre-warehouse model, and a small warehouse integrating warehousing, sorting and distribution is set up in multiple small community groups. Due to the small warehouse layout around the community users, the distribution efficiency is effectively improved, the product loss is reduced, and the home commitment of one hour or even half an hour is easily achieved. At present, some wellknown fresh e-businesses such as Dingdong, Missfresh and Meituan all use the pre-warehouse model.
Community retail model. The model is mainly community group and community inn. A community group leader is selected as the convener in the community, and the products are released and purchased through Wechat and other communication softwares. After purchasing a certain amount, the products are distributed uniformly. For example, Meituan Optimization and Melon Ripening are the ways of community group. The community fresh station will open small physical stores in the community. Small physical stores have vending machines, small physical operators and mobile sales vehicles, such as Direct Marketing of Xinfadi and Meat Federation.

"To home + To store" model. This is a new and more common mode in recent years. This mode has both physical stores and online shopping. Through timely delivery or even one-hour delivery or appointment of delivery time, it provides consumers with a variety of shopping experiences that can be delivered to the store and home. Wumei, Dmall, Convenience Bee, Fresh Hema and so on all adopt this way.

Platform model. The platform model makes use of the existing platform sales advantages, increases the distribution service of fresh sales, and achieves the purpose of fresh sales. The main difference between the general platform mode and the mode of front warehouse or "to store" is that the platform mode uses the existing platform as the marketing window, and the platform does not store fresh goods, but provides distribution services for offline supermarkets and fresh vegetable stores. For example, Jingdong to Home is the platform of fresh sales model.

\subsection{Four development stages of fresh food e- commerce}

The fresh food e-commerce market in China has 
experienced four development stages. Delivery time and operation mode are the main "watershed" of the four development stages. The first stage of fresh e-commerce is still in its infancy. The form of central warehouse in urban areas is booming, and fresh e-commerce is mainly delivered on the next day. Due to the unstable product quality, uncertain delivery time, less use of cold chain logistics and other factors, the use frequency of fresh ecommerce is not high, and the consumption experience of consumers is poor. Most of them still focus on store consumption and are not used to online purchasing of fresh food. In the second stage, with the gradual expansion of online sales, especially the relatively frequent online payment, with the increasingly complete urban distribution, the development of fresh e-commerce ushered in a golden age. The delivery time of fresh ecommerce is changed from "Arrive Next Day" to "Arrive Today", which not only improves the product quality, but also wins the recognition of consumers. In the third stage, with the gradual perfection of the front-end warehouse and the popularity of the payment methods such as WeChat and Alipay, the consumption mode such as takeaway and catering is popularized by the majority of consumers. "Arrive Today" is upgraded to "Arrive within Two Hours" or even one hour or half an hour. Coupled with the fresh e-commerce coupons, red envelope coupons stimulate marketing, fresh e-commerce really into thousands of households. Nowadays, the contactless service mode has played a role of booster for the vigorous development of fresh e-commerce.

\section{Transformation of circulation model of fresh agricultural products}

\subsection{Traditional circulation model of fresh agricultural products}

The industry chain of fresh food industry is long. Because the fresh products are easy to corrode and damaged, the supply chain is relatively complex. Therefore, the fresh industry chain has established a relatively stable supply model, which is shown in Figure 1.

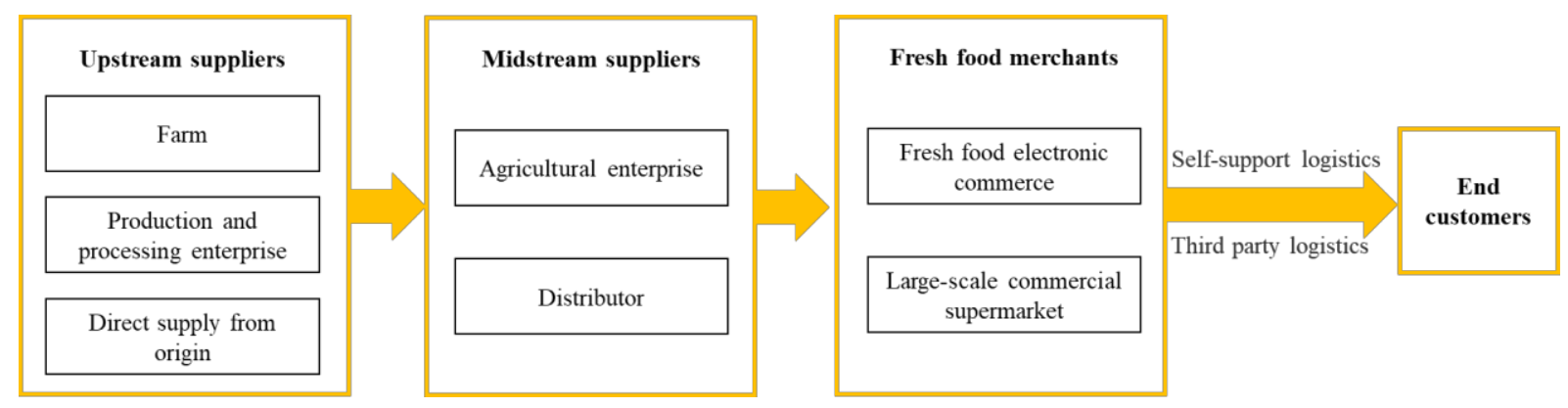

Figure 1. Industrial chain diagram of traditional fresh food industry

In the traditional circulation mode of fresh agricultural products, there are many intermediate links, complex storage and transportation process, high cost consumption and easily affected quality. At the same time, the information from the farmers to the consumer market is not equal, the supply and demand relationship is not balanced, and the price fluctuation is easy to occur.

\subsection{E-commerce circulation model of fresh agricultural products}

Fresh e-commerce has got rid of the traditional supply mode of fresh agricultural products, and even many fresh e-commerce have adopted the operation mode of local direct purchasing and buyers entering the field, that is, fresh e-commerce employs a large number of fresh buyers, in order to provide consumers with more and more highquality, richer and more popular fresh products, and directly purchase with local farmers, so as to achieve the direct purchasing industry without middlemen and intermediate links It not only reduces circulation links to the greatest extent, reduces the consumption of fresh products, but also reduces the purchase cost of enterprises, and delivers the most "first-hand" fresh goods that can be seen and touched to the dining table.

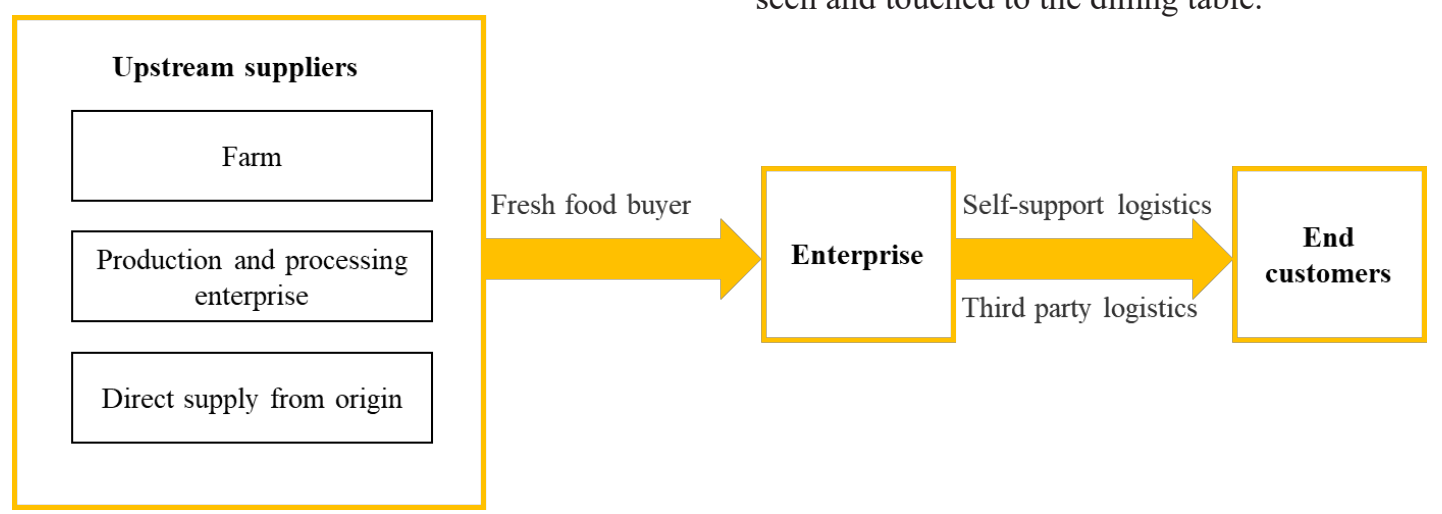

Figure 2. Industrial chain diagram of e-commerce fresh food industry 


\subsection{Comparison of circulation models of traditional and e-commerce agricultural products}

The traditional circulation mode of agricultural products has many intermediate links, large loss and high rate of price increase. According to the Fresh supply chain industry research report in 2018 issued by China Merchants Securities Co., Ltd, the price increase rate from the upstream supplier's fresh production farmers to the origin purchasers is about $12 \%$, while the fresh loss rate is about $2 \%$; from the origin purchasers to the wholesale market, the average price increase rate of each level of wholesale market is about $15 \%$, and the loss rate is about $6 \%$; from the wholesale market to the supermarket, the price increase rate is $20 \%$, and the loss rate is $5 \%$; from the supermarket to the consumer, the price increase rate is about $35 \%$, and the loss rate is $8 \%$. In the whole process of fresh food sales, the increase rate from the place of origin to consumers is close to $100 \%$, and the loss rate is more than $30 \%$. In different categories of fresh products, the increase rate and loss rate of vegetables, fruits and seafood were higher. Fresh e-commerce's circulation of agricultural products has got rid of many intermediate links, from the most primary suppliers to e-commerce enterprises and then to consumers. It has only experienced two transportation and distribution links, and only ecommerce enterprises increase the price, which greatly reduces the rate of increase and loss, and part of the profit is transferred to farmers and end consumers.

\section{Current situation of consumer demand of fresh food}

\subsection{Huge consumption potential of fresh food market}

China's fresh food consumption channels mainly include four categories. According to the statistical data in Research Report on Chinese fresh e-commerce industry in 2018 issued by China Business Industry Research Institute, the agricultural trade market is still the main channel of fresh food sales, accounting for $73 \%$, followed by supermarkets, accounting for about $22 \%$, and fresh ecommerce as the sales channel is only $3 \%$. For example, in 2017, the transaction volume of fresh food market was 1789.7 billion yuan, and that of fresh e-commerce market was 141.8 billion Yuan in the same year. In terms of transaction volume, the transaction volume of fresh ecommerce market accounted for nearly $8 \%$ of the total transaction volume of fresh food market. According to the data of China Statistical Yearbook, the consumption of fresh food increased from 312 million tons in 2014 to 332 million tons in 2018. According to the per capita consumption of fresh food of residents from 2013 to 2019, vegetables, fresh melons and fruits, meat, poultry, eggs and milk products also have a major upward trend, and the per capita consumption of fresh food is increasing year by year. This trend is most obvious in the consumption of fresh food over the years. In the fresh food consumption, the increase of meat consumption is the most significant. It is shown in Table 1.

Table 1. Average consumption of fresh food of Chinese residents from 2013 to 2019 (unit: kg)

\begin{tabular}{lllllllll}
\hline variety & Vegetable & $\begin{array}{l}\text { Melon and } \\
\text { fruit }\end{array}$ & Meat & Poultry & Egg & Milk & $\begin{array}{l}\text { aquatic } \\
\text { product }\end{array}$ & Total \\
\hline 2013 & 94.9 & 37.8 & 25.6 & 7.2 & 8.2 & 11.7 & 10.4 & 195.8 \\
2014 & 94.1 & 38.6 & 25.6 & 8.0 & 8.6 & 12.6 & 10.8 & 198.3 \\
2015 & 94.9 & 40.5 & 26.2 & 8.4 & 9.5 & 12.1 & 11.2 & 209.1 \\
2016 & 96.9 & 43.9 & 26.1 & 9.1 & 9.7 & 12.0 & 11.4 & 210.9 \\
2017 & 96.1 & 45.6 & 26.7 & 8.9 & 10.0 & 12.1 & 11.5 & 212.2 \\
2018 & 93.0 & 47.4 & 29.5 & 9.0 & 9.7 & 12.2 & 11.4 & 221.2 \\
2019 & 95.2 & 51.4 & 26.9 & 10.8 & 10.8 & 12.5 & 13.6 & 222.1 \\
Average & 95.019 & 43.60 & 26.66 & 8.77 & 9.50 & 12.17 & 11.47 & 207.19 \\
\hline
\end{tabular}

Source: Data summary according to the National Bureau of Statistics website

However, with the gradual increase of e-commerce market share, the expansion of food consumption upgrading space, the demand for fresh products continues to grow. The transaction scale and consumer recognition of fresh e-commerce still have great potential to improve.

\section{2 "Fresh food + e-commerce" becomes an important channel of fresh food consumption}

China's annual fresh consumption is huge. Although it is still dominated by the traditional offline consumption mode, "fresh + e-commerce" mode has become one of the important channels of fresh consumption. The study found that consumers have brand effect in the use of fresh ecommerce. Most consumers will have 3-5 fresh ecommerce apps in their mobile phones, and most of them will have 1-2 e-commerce apps for large supermarkets, such as Dmall and Yonghui Supermarket. Most of the others are the users of Missfresh, Fresh Hema, Meituan, Jingdong to Home and Dingdong. When consumers choose fresh e-commerce, they will compare the prices of different categories. Therefore, the products with discounts, coupons or preferential red envelopes will attract consumers' attention and purchase. At the same 
time, the satisfaction of previous purchase will affect the purchase choice and frequency. The factors that affect consumers' purchase satisfaction mainly include: Commodity safety, variety, commodity quality and freshness, whether there is short weight, the delivery time of the goods, whether the appointment time is allowed, whether the classified package is provided, whether the delivered goods are damaged.

According to the Research Report of China Fresh Online Shopping in 2017 issued by China International Capital Corporation, among the users who use the Internet to buy fresh products, more than $72 \%$ of the consumers who consume fresh products more than once a week buy vegetables and $61.2 \%$ of the consumers buy fruits, while the proportion of meat, poultry and eggs, cooked food, dairy products, aquatic products, frozen drinks are $58.1 \%$, $48.6 \%, 47.4 \%, 46.7 \%$ and $45.6 \%$ respectively.

\subsection{Characteristics of consumer demand of fresh food e-commerce}

As fresh goods are just needed in the market, the upgrading of fresh goods market continues to accelerate, and the transformation from state-owned vegetable market to fresh e-commerce and from seller's market to Seller's market is rapidly completed. The scale of fresh trade in China is growing steadily, and according to The New Retail Promotes the Fifth Reform of Fresh Food Industry issued by Senway Network, the growth rate of fresh trade will maintain at more than $6 \%$ from 2020 to 2023 . It is estimated that in 2023, the transaction scale of fresh food market will reach 2.62 trillion yuan, and the scale of ecommerce fresh food market will exceed 800 billion yuan. In terms of fresh e-commerce shopping crowd, the trend is still young, and the online consumption mode under the fast pace of work and life is more likely to be favoured by young people. But at the same time, the proportion of China's elderly population is increasing, and affected by travel restrictions and price sensitivity, the home mode of fresh e-commerce in the community is also being welcomed by more and more elderly people. Not only that, fresh e-commerce app, which has more and more friendly interface and more convenient payment method, is also easy for many elderly people to use.

\section{Platform development strategy of fresh food e-commerce based on ReTech}

In recent years, fresh retail and technology integration is very close, there is still a trend of accelerated development. In the retail format, the application of artificial intelligence, big data, block chain, cloud computing and other technologies in the front-end and back-end of the retail format not only greatly improves the operation efficiency, but also has the effect of user identification, insight, accessibility and service; it realizes two-way tracking of consumers and agricultural products sources, and also has the effect of product supply chain traceability. Moreover, the system layout of the integration of production, supply and marketing of agricultural products runs through the fresh consumption chain of cultivation, processing, logistics, distribution and retail. At the same time, the combination of back-end automatic sorting system and mobile handheld terminal facilitates the picking personnel to find the corresponding goods at any time. The mobile handheld terminal corresponds to the receiving, returning, putting on the shelves, checking, moving, packing, rechecking, as well as the location, name, number and quantity of the goods one by one, and even has built a unique hanging transmission in the supermarket stores to bring the transportation Picking goods ready for distribution saves a lot of manpower and material resources and time, improves work efficiency; a lot of online payment will make it easier for the retail industry to obtain customer resources, more accurate customer portraits, easier for consumers to query bills, reduce queuing time, and enhance user experience and satisfaction.

This is not the only way for high-tech enabled retail formats. Artificial intelligence, face recognition, voice recognition, intelligent payment, remote control equipment and other intelligent devices will inject new vitality and profit growth points into the retail formats.

\section{Platform development strategy of fresh food e-commerce}

\subsection{Establish strict product quality supervision system}

It is very important to perfect product quality supervision system for the marketing of fresh agricultural products. In particular, it's important that fresh e-commerce enterprises as a virtual platform, consumers' evaluation and feeling of goods. Therefore, strict product quality supervision system and high-quality fresh products are the magic weapon for the success of fresh e-commerce. The whole industry chain of artificial intelligence monitoring and cold chain logistics management technology will provide guarantee for the quality of fresh products. From the field harvesting, packaging, loading and unloading, handling, warehousing and other circulation links of the whole industrial chain, the whole process of cold chain seamless docking and artificial intelligence monitoring are achieved, which not only ensures the quality of goods, but also guarantees consumers to purchase fresh food materials at ease.

\subsection{Seek truth and innovation in product display}

The e-commerce shopping experience of freshest products is displayed to consumers through photos. Due to the characteristics of lighting, angle, and even embezzlement of photos, it will lead to consumers' disapproval and even return, reduce consumers' expectation, trust and evaluation, and even affect the probability of re purchase. The impact on fresh e-commerce is fatal. Therefore, it is the key point of consumers' first cognition of fresh products to show and clearly describe the products. At the same time, the introduction of new media such as short 
video and live broadcast will help to better display the products in an all-round way and increase the favour of consumers in purchasing.

\subsection{Strengthen the friendliness and recognition of fresh food e-commerce APP}

Fresh e-commerce app is more convenient for consumers to sit at home for careful price comparison and research. Therefore, the friendliness and recognition of fresh ecommerce app interface directly affect the possibility of consumers' purchasing. Intuitive, convenient and quick to find the needed goods, friendly to provide a combination of goods, timely display of product information will increase the favour of consumers. Many fresh e-commerce companies do make a big difference in app interface and service. We not only made a detailed classification and preferential product portfolio, but also put discount products, discount products or key recommended products on the home page of app to update at any time. Red envelope coupons, discount coupons and full reduction policies are clearly visible, and even some apps provide product price comparison function, which reduces the trouble of price comparison for consumers. In order to provide more friendly services, the cooking and eating methods of the products are also introduced to the products, and a community is established to exchange and share the purchase experience of the consumers. More preferential policies than offline are also one of the means to attract consumers to use e-commerce app for shopping. The past shopping list and frequently purchased goods recommendation increase the possibility of consumer's purchase. There are also some e-commerce apps integrated with short video and live broadcast, which further increased consumer popularity and recognition.

\subsection{Ensure timely delivery, good quality and enough quantity}

When consumers choose fresh e-commerce, they are more interested in the on-time delivery of e-commerce. From the perspective of customer experience, fresh e-commerce is speeding up its development in the direction of getting closer to consumers and faster distribution. For example, Jingdong to Home and Meituan Shopping can cooperate with offline supermarkets, retail stores and convenience stores to deliver within 1-2 hours. Fresh Hema and Dingdong shopping can be delivered within 1 hour; Dmall delivery is mainly based on the appointment system, with the delivery period of 30 minutes; Miss fresh promises to deliver within 1 hour in the first and second tier cities in 2019, while in cities such as Beijing and Shanghai, it will be delivered within 1 hour. In 2020, it can be shorted to 30 minutes. It can be seen that the accuracy of fresh ecommerce distribution is getting higher and higher. With the increasing personalized requirements of consumers, the distribution mode of some fresh e-commerce is also changing. For example, packaging and distribution in bags has become a must for the purchase of fresh goods.

\subsection{Strengthen agricultural products reverse tracking linkage}

The back tracking linkage and whole process traceability of agricultural products are the guarantee of fresh products. The quality of fresh agricultural products is greatly affected and the price gap is also large due to the differences in origin, harvesting method and transportation process. For example, cherry, kiwifruit, fungi and other products are affected by the origin, taste and quality are different, and the price is not the same. Due to the different characteristics of fresh e-commerce compared with traditional supermarkets, it can be more prepared for product description, and consumers will pay special attention to the origin of fresh agricultural products, logistics and distribution methods. At the same time, product photos, videos and description details are the basis to measure product quality. The characteristics of nonphysical goods require consumers to make purchase decisions through details. Therefore, the back tracking and whole process traceability of agricultural products can guarantee the quality and safety of fresh products for consumers.

\section{References}

1. Calloway E E, Seligman H K, Boyd L W, et al. Development and testing of the FRESH Foods Survey to assess food pantry clients' dietary behaviours and correlates[J]. Public Health Nutrition, 2019, 22(12):19.

2. Curry G N, Koczberski G, Inu S M. Women's and Men's Work: The Production and Marketing of Fresh Food and Export Crops in Papua New Guinea[J]. Oceania, 2019, 89(2):237-254.

3. Wang H H, Hao N, Zhou Q, et al. Is fresh food shopping sticky to retail channels and online platforms? Evidence and implications in the digital era[J]. Agribusiness, 2019, 35(1): 6-19.

4. Wang M, Zhao L, Herty M. Joint replenishment and carbon trading in fresh food supply chains[J]. European Journal of Operational Research, 2019, 277(2): 561-573.

5. Guo C, Mujumdar A S, Zhang M. New Development in Radio Frequency Heating for Fresh Food Processing: A Review[J]. Food Engineering Reviews, 2019, 11(1):29-43.

6. Mcknight D H, Choudhury V, Kacmar C. Developing and Validating Trust Measures for e-Commerce: An Integrative Typology[J]. Information Systems Research, 2002, 13(3):344-359.

7. Ermakova T, Hohensee A, Ines Orlamünde, et al. Privacy-invading mechanisms in e-commerce - A case study on German tourism websites[J]. International Journal of Networking and Virtual Organisations, 2019, 20(2):105-109.

8. Mushtaq R, Ahmad N, Rextin A, et al. Improving Usability of User Centric Decision Making of MultiAttribute Products on E-commerce Websites[J]. 2020, 23(1): 1-10. 
9. Yanyong. Research of Order Allocation of Ecommerce Logistics Service Supply Chain Considering Customer Evaluation[J]. International Journal of Plant Engineering and Management, 2020, 15(1):1-13.

10. Bergstein H, Nesin B. Five considerations for marketers navigating the changing US beverage alcohol e-commerce landscape[J]. Journal of Digital \& Social Media Marketing, 2020, 8(13): 33-45.

11. Rabiah A S, Fahlevi M, Juhandi N, et al. Haruskah EPayment Trust Diterapkan E-Commerce Sebagai Faktor Kepuasan Konsumen? [J]. E-Jurnal Manajemen Universitas Udayana, 2020, 9(7):27242743.

12. Liu G, Fei S, Yan Z, et al. An Empirical Study on Response to Online Customer Reviews and ECommerce Sales: From the Mobile Information System Perspective[J]. Mobile Information Systems, 2020(83):1-12.

13. Suliano M R. Strategi Komunikasi Pemasaran ECommerce Boogie.id Menggunakan IMC Model Dwi Sapta[J]. Jurnal Komunikasi Global, 2020, 9(2):300315.

14. Ramadhan M, Ariyanti D O, Ariyani N. Pencurian emoney pada e-commerce dalam Tindak Pidana Cybercrime sebagai Tindak Pidana Ekonomi[J]. Reformasi Hukum, 2020, 24(2):169-188.

15. Algiffary M A, Wahab Z, Shihab M S, et al. Pengaruh Celebrity Endorser, Online Advertising dan Word of Mouth terhadap Minat Beli Konsumen pada ECommerce Tokopedia[J]. AMAR (Andalas Management Review), 2020, 4(2):16-31. 